\title{
A CORRELATION BETWEEN THE GAS AND LIQUID PERMEABILITIES OF BEECH WOOD HEAT-TREATED IN HOT WATER AND STEAM MEDIUMS
}

\author{
Hamid Reza Taghiyari ${ }^{1}$, AisonaTalaei ${ }^{1}$, Ali Karimi ${ }^{2}$
}

\begin{abstract}
Heat-treatment, a major method of wood modification for improving dimensional stability and natural durability, has been studied considerably in the scientific literature. This study will focus on the effect of heat-treatment on permeability, an important physical property of wood by subjecting beech samples to two different mediums of hot water and steam, as well as in two buffered hot water of $\mathrm{pH} 7$ and 8 . Hydrothermal treatment caused gas permeability to decrease to its lowest value among the treatments (91.6\% decrease comparing the control treatment). Hydrothermal treatment in buffered hot water of $\mathrm{pH}$ 8 made the lowest impact on gas permeability (12.3\% decrease). The decrease in gas permeability was due to settlement of extractives on vessel perforation plates. Gas permeability showed a highly significant correlation with the amount of swelling in radial direction. Low correlation was found between liquid permeability with water absorption and the amount of swelling. Gas permeability is considered a suitable criterion for predicting the amount of swelling in beech wood.
\end{abstract}

Keywords: Heat treatment, hydrothermal, hygrothermal, wood modification, wood swelling.

\section{INTRODUCTION}

Of all the various wood modification processes that have been studied, thermal modification is by far the most commercially-advanced. It has long been recognized as a potentially useful method to improve the dimensional stabilization of wood and increase its decay resistance (Hill 2006).

Tiemann (1915) was one of the first researchers to report on the effect of high-temperature treatment upon the physical properties of wood. He heated air-dried wood in superheated steam at $150^{\circ} \mathrm{C}$ for 4 hours, which reduced the subsequent moisture sorption by $10-25 \%$, with relatively low reductions in strength found in most cases. Heat treatment significantly reduces the tangential and radial swelling. The desired changes begin to occur at about $150^{\circ} \mathrm{C}$, and the changes continue as the temperature is increased in stages (Gunduz et al. 2009). At around $270^{\circ} \mathrm{C}$, there is a significant change in the reaction kinetics due to the onset of an exothermic reaction. What is less certain is the exact points at which the different reactions become dominant (Stamm et al. 1946).

Thermal modification is invariably performed between the temperatures of $180^{\circ} \mathrm{C}$ and $260^{\circ} \mathrm{C}$, with temperatures lower than $140^{\circ} \mathrm{C}$ resulting in only slight changes in material properties and higher temperatures resulting in unacceptable degradation to the substrate (Hill 2006). The presence of water, or water vapor, affects the chemistry of thermal modification and heat transfer within the wood (Burmester 1981). Under dry treatment conditions, the wood is dried prior to thermal modification, or water is removed by the use of an open system, or a re-circulating system equipped with a condenser. In closed systems,

\footnotetext{
Shahid Rajaee Teacher Training. University, Civil Engineering Faculty, Wood Science \& Technology Dept., Lavizan, Shabanloo St., 21-22970021 Tehran, Iran.. htaghiyari@yahoo.com

${ }^{2}$ Institute of Tropical Forestry \& Forest Products (INTROP), University of Putra Malaysia, Serdang, Selangor, Darul Ehsan, 43400 Malaysia Corresponding author: htaghiyari@srttu.edu

Received: 23.04.2011 Accepted: 21.08.2011
} 
water evaporated from the wood remains as high-pressure steam during the process. Steam can also be injected into the reactor to act as a heat-transfer medium, and can additionally act as an inert blanket to limit oxidative processes. Such steam treatment processes are referred to as hygro thermal treatments. Where the wood is heated in water, this is known as a hydrothermal process (Hill 2006). Heat treatment mediums also affects the physical and mechanical properties; specimens that were hydrothermally treated had higher mass loss and dimensional stability and lower MOR and MOE compared to hygro thermally treated ones at the same temperature of $180^{\circ} \mathrm{C}$ (Talaei et al. 2011). Studies of the thermal treatment of wood above $300^{\circ} \mathrm{C}$ are of limited value, due to severe degradation of the material; there is also evidence to show that there is an abrupt change in the degradation kinetics close to this temperature (Elder 1991). Modern thermal modification processes are limited to temperatures no higher than $260^{\circ} \mathrm{C}$.

Temperature ranges from $150^{\circ} \mathrm{C}$ to $230^{\circ} \mathrm{C}$ are generally used, because hydrolysis is very slow at lower temperatures, whereas cellulose degradation begins to occur in the region $210-220^{\circ} \mathrm{C}$. Cellulose degradation becomes predominant at $270^{\circ} \mathrm{C}$. A sharp increase in the free-radical content of wood was also found when wood was heated at temperatures above $200^{\circ} \mathrm{C}$ (Garrote et al. 1999). The heat-transfer property of nano-silver particles on mechanical properties of heat-treated poplar was also reported to aggravate the effects of heat-treatment (Taghiyari 2011).

As to the effects of heat-treatment on the fluid transfer property of wood, reduction of wood swelling with increasing temperature and duration of thermal treatment was often attributed to hemicelluloses destruction. However, structural modifications and chemical changes of lignin are suggested to be also involved in the process (Repellin and Guyonnet 2007). Furthermore, Borrega and Karenlampi (2009) indicate that reduction in hygroscopicity is not only due to mass loss but another mechanism may also exist. They suggest that this mechanism might be related to irreversible hydrogen bonding in the course of water movements within the pore system of the cell walls. Also, thermal treatment was reported to reduce the value of mass diffusivity in Populus robusta but did not significantly change air permeability values (Rousset et al. 2004).

There are few studies on permeability of heat-treated woods. The present study is, therefore, aimed at finding the effects of heat-treatment on gas and liquid permeability of heat-treated solid woods and finding possible correlations and trends with physical and mechanical properties of beech wood.

\section{MATERIALS and METHODS}

\section{Specimen Procurement}

25 blocks of $150 \times 50 \times 50 \mathrm{~mm}$ were prepared from beech logs (Fagus orientalis L.). All blocks were free from any checks, knots, rots, or other visual defects. They were randomly divided into 5 groups of control, hydrothermal, hygrothermal, buffered hot water of $\mathrm{pH} 7$ and 8. From each block, five longitudinal specimens were cut for permeability measurement.

\section{Heat-Treatment Process}

Blocks were first air-dried; then for hydrothermal treatment, they were placed in an autoclave, filled up with distilled water, or buffered hot water of $\mathrm{pH} 7$ or 8 , and heated at $180^{\circ} \mathrm{C}$ for 1 hour. For hygrothermal treatment, blocks were located in a vessel and steamed at $180^{\circ} \mathrm{C}$ for 1 hour at $6-7$ bars. Once were treated, blocks were brought to a conditioning room where they were conditioned at $20^{\circ} \mathrm{C}$ and $65 \%$ relative humidity, along with untreated specimens, for 2 months until equilibrium moisture content.

Since the $\mathrm{pH}$ value of hydrothermal medium changes during heat treatment, buffered hot waters ( $\mathrm{pH}$ 7 and 8) were used as the medium keeping $\mathrm{pH}$ constant during hydrothermal treatment. Buffered hot 
water of $\mathrm{pH} 7$ comprised $411.75 \mathrm{ml} \mathrm{Na}_{2} \mathrm{Hpo}_{4} \cdot 2 \mathrm{H}_{2} \mathrm{O}(0.2 \mathrm{M})+88.25 \mathrm{ml} \mathrm{C}_{6} \mathrm{H}_{8} \mathrm{O}_{7} \cdot \mathrm{H}_{2} \mathrm{O}$; and $\mathrm{pH} 8$ comprised $483.25 \mathrm{ml} \mathrm{Na}_{2} \mathrm{Hpo}_{4} \cdot 2 \mathrm{H}_{2} \mathrm{O}(0.2 \mathrm{M})+13.75 \mathrm{C}_{6} \mathrm{H}_{8} \mathrm{O}_{7} \cdot \mathrm{H}_{2} \mathrm{O}$ (Alexeyev 1967). All other treatment conditions of both buffered hot waters remained the same as in the hydrothermal treatment.

\section{Gas Permeability Measurement}

Longitudinal gas permeability was measured by an apparatus with milli-second precision designed and built by the first author based on the microstructure porosity of wood (Siau 1971, Taghiyari and Efhami 2011). All gas permeability specimens were cylindrical, $18 \mathrm{~mm}$ in diameter and $30 \mathrm{~mm}$ long in the wood longitudinal direction; cylindrical specimens were prepared using a hole-saw (a hollow-saw). Heat-treatment of blocks made it impossible to prepare the samples by a lathe and therefore the gas permeability values may not be considered as good criteria for permeability values of the wood and should better be used for comparison of different treatments of the present study (Taghiyari and Sarvari-Samadi 2010). Measurements were done using the falling water volume displacement method instructions (Siau 1995). Connection between the specimen and holder of the apparatus was made fully air-tight. A pressure gauge with milli-bar precision was connected to the whole structure to monitor pressure gradient $(\Delta \mathrm{P})$ and vacuum pressure at any particular time as well as height of water column.

Three measurements were taken for each specimen. Superficial permeability coefficient was then calculated using Siau's equations (equations 1 and 2) (Siau 1995). The superficial permeability coefficients were then multiplied by the viscosity of air $\left(\mu=1.81 \times 10^{-5} \mathrm{~Pa} s\right)$ for the calculation of the specific permeability $\left(K=k_{g} \mu\right)$.

$$
\begin{gathered}
k_{g}=\frac{V_{d} C L\left(P_{a t m}-0.074 \bar{z}\right)}{t A(0.074 \bar{z})\left(P_{a t m}-0.037 \bar{z}\right)} \times \frac{0.760 \mathrm{mHg}}{1.013 \times 10^{6} \mathrm{~Pa}} \\
C=1+\frac{V_{r}(0.074 \Delta z)}{V_{d}\left(P_{a t m}-0.074 \bar{z}\right)}
\end{gathered}
$$

\section{Where:}

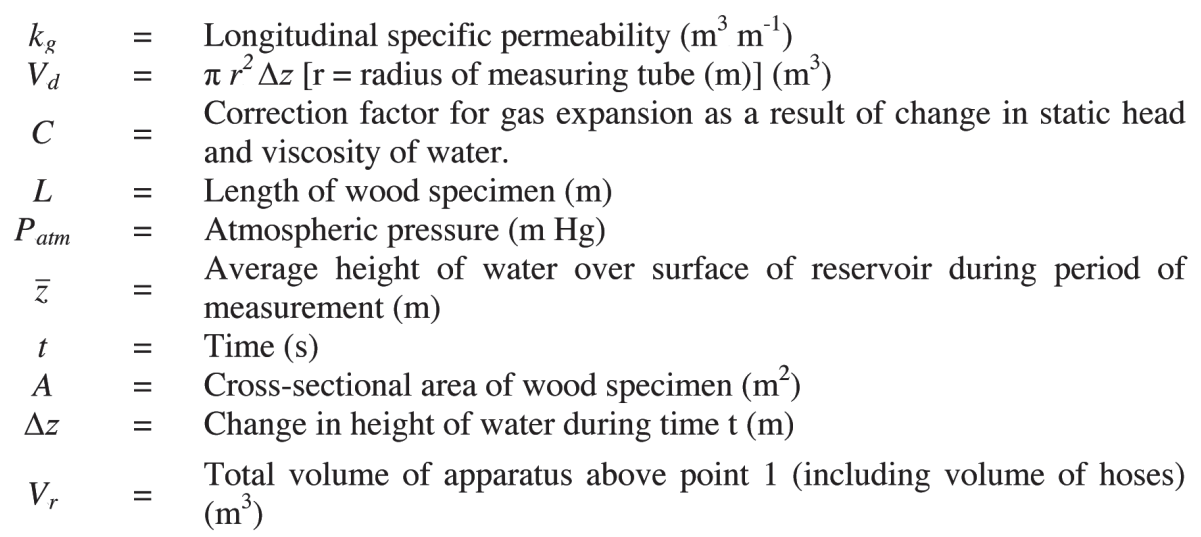




\section{Liquid Permeability Measurement}

Liquid permeability was measured using the Rilem test method II.4 according to Rilem Commission 25, PEM, Test Method 1154 by International Union of Laboratories and Experts in Construction Materials, Systems, and Structures; penetration tests were conducted under laboratory conditions according to ASTM E-514. Two times were measured:

1- The time the first drop of water falls off the bottom surface of the $3 \mathrm{~cm}$ long specimen;

2- The time the level of water in Rilem tube lowers by $50 \mathrm{~mm}$ in the glass tube (that is, 6.6 CC of water).

Relationships between gas time with the-first-drop time, as well as 50-mm-lowering time, were then measured.

\section{Microscopic Observation}

Blocks of $20 \times 20 \times 20$ mmwere cut from each treatment and were kept in distilled water for 48 hours. Transverse sections of $20-25 \mu \mathrm{m}$ in thickness were cut by a Jung Heidelberg slicing microtome. The sections were stained with safranin and then dehydrated in a graded series of ethanol $(50 \%, 75 \%$, and $96 \%$ ), and finally in xylol to make them ready to be mounted on microscopic slides. Images were taken by a digital optical microscope, magnification of 40 .

\section{Statistical Analysis}

Statistical analysis was conducted using SAS software program, version 9.1 at $99 \%$ confidence level. Cluster and regression analysis was carried out using SPSS software, version 16.

\section{RESULTS}

\section{Longitudinal Gas Permeability}

The average longitudinal specific gas permeability of the control specimens was measured to be 13.5 $\times 10^{-13} \mathrm{~m}^{3} \mathrm{~m}^{-1}$ (Fig. 1). Hydrothermal heat-treatment resulted in gas permeability decreasing to its lowest value of $1.1 \times 10^{-13} \mathrm{~m}^{3} \mathrm{~m}^{-1}(91.6 \%$ decrease). Hygrothermal heat-treatment also made a gas permeability decrease by $85.8 \%\left(1.9 \times 10^{-13} \mathrm{~m}^{3} \mathrm{~m}^{-1}\right)$. Although buffered hot water of $\mathrm{pH} 7$ resulted in the mitigation of the decreasing effect of hydrothermal treatment, still gas permeability value was quite low $\left(3.7 \times 10^{-13}\right.$ $\left.\mathrm{m}^{3} \mathrm{~m}^{-1}\right)$. Buffer- 8 medium, on the other hand, resulted in gas permeability decreasing only by $12.3 \%$ $\left(11.9 \times 10^{-13} \mathrm{~m}^{3} \mathrm{~m}^{-1}\right)$.

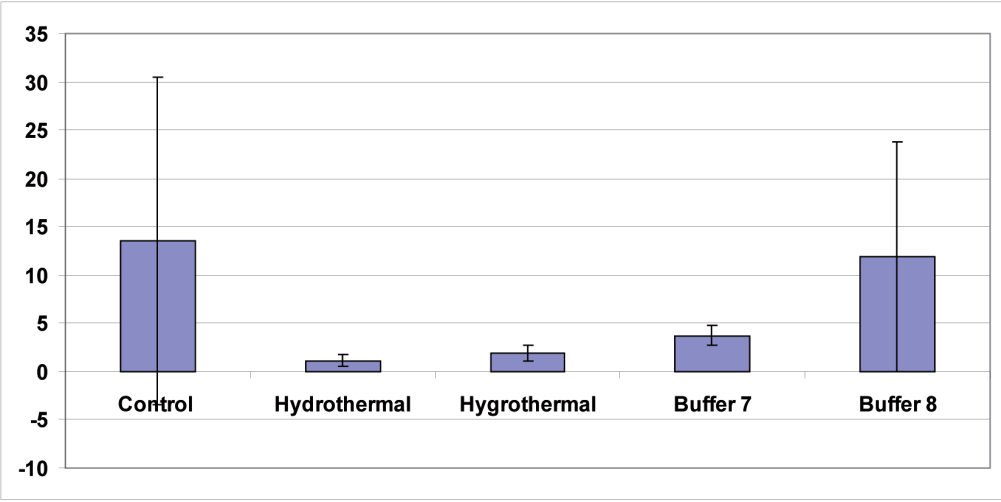

Figure 1. Specific gas permeability values for different treatments of beech specimens $\left(\times 10^{-13} \mathrm{~m}^{3} \mathrm{~m}^{-1}\right)$ (high error bars indicate scattered data

in each treatment showing the nature of permeability in beech wood) 


\section{Longitudinal Liquid Permeability}

Minimum mean time for the $1^{\text {st }}$-drop was measured to be 126.8 minutes in buffered hot water of $\mathrm{pH} 7$, comparing with 183.1 (min) in control specimens. In hydrothermal specimens, no time was observed as to the fact that there was no first drop even when the water level had decreased $50 \mathrm{~mm}$ in the Rilem test tube.

Minimum time for 50-mm water-column-lowering in Rilem glass tube was measured to be 354 minutes in buffered hot water of $\mathrm{pH}$ 7. Maximum 50-mm lowering time was observed in hygrothermal specimens (3396.5 minutes). Mean 50-mm lowering time in control specimens was 1117.6 minutes.

\section{DISCUSSION}

Perforation plates in beech wood is comprised of both simple and scalariform type. Furthermore, tyloses may be observed in different parts and locations of vessel elements (Taghiyari 2012). Also, extractives and pitch deposits were reported to have different concentrations in different parts and heights of trees (Flynn 1995, Koch 1996, Rice and D’Onofrio 1996, Taghiyari et al. 2010, Taghiyari and Sarvari Samadi 2010, Taghiyari et al. 2011). These may contribute to the wide scatter of data in each treatment (the high error bars in Fig. 1). In the present study, microscopic imaging showed evidence of settlement of extra extractives on perforation plates and cell walls caused by hydrothermal heat treatments (Fig. 2). Probable occurrence of these settlements on vessel perforation may justify the drastic decrease in gas permeability in hydro thermolysis treatment (Fig. 1). Deposition of extractives on cell wall has previously been reported in other studies (Boonstra et al. 2006). However, microscopic imaging of buffered hot water of $\mathrm{pH} 8$ specimens showed no deposition of extractives, and vessel elements were nearly wide open (Fig. 3). This would justify the high gas permeability value of this treatment (Fig. 1).

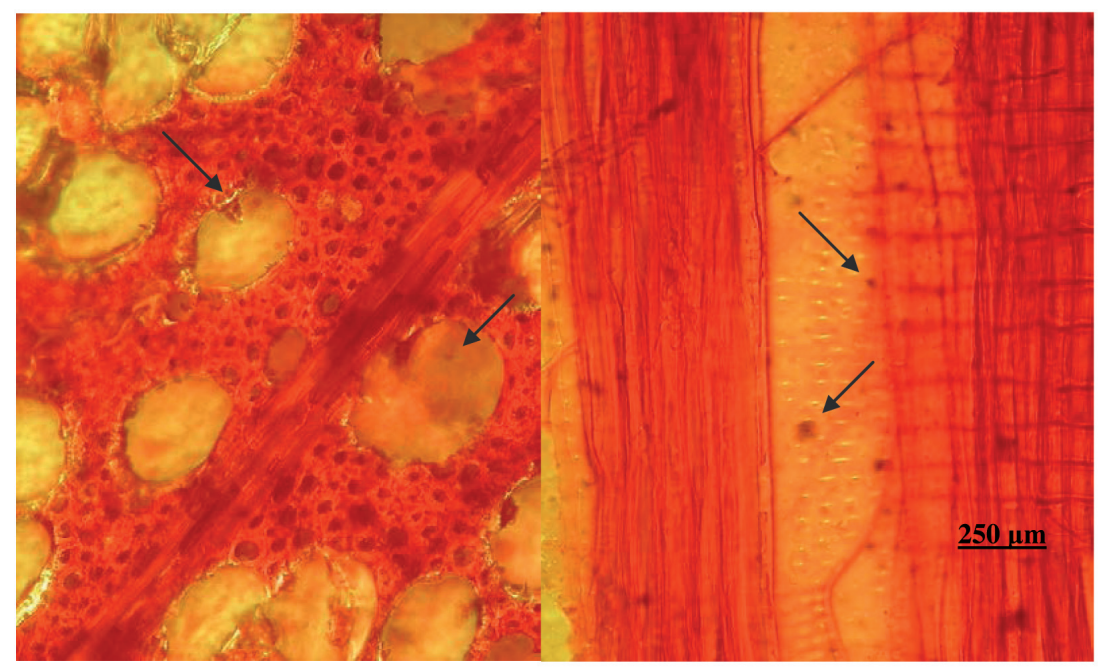

Figure 2. Extractives blocking vessel elements (left) and settling on cell walls (right) in hydrothermal heat treatment 


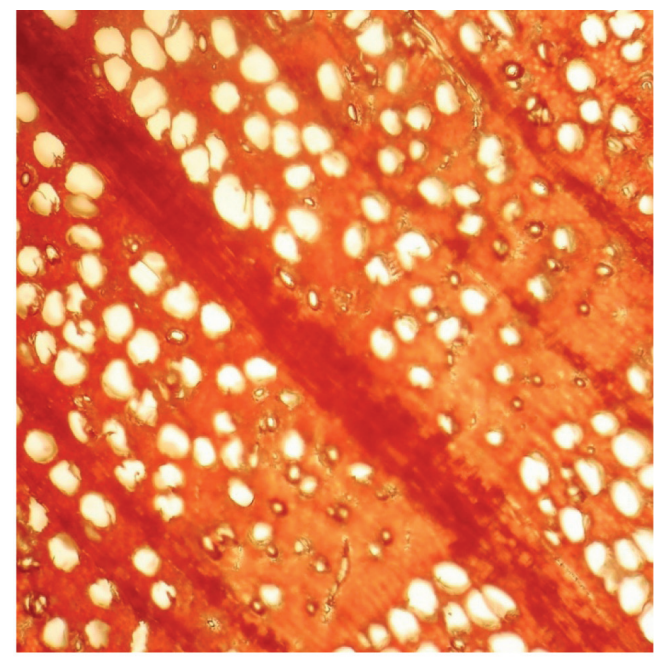

Figure 3. Vessel elements are wide open in specimens treated in buffered hot water of $\mathrm{pH} 8$

Regression analysis of gas permeability with water absorption (WA) as well as the amount of swelling in different directions (Radial, Tangential, and Longitudinal) showed there are positive relations in all cases (Table 1). Significant correlation was only observed between radial swelling with gas permeability. Still, good correlation, although not significant, was also found between tangential swelling with gas permeability. Correlation between gas permeability with longitudinal swelling as well as water absorption was neither significant nor high. Regression values between liquid permeability $\left(1^{\text {st }}\right.$ drop, and $50-\mathrm{mm}$ lowering time) were all very low and insignificant.

Table 1. Regression analysis results for correlations between gas and liquid permeability with water absorption as well as swelling in radial, tangential, and longitudinal directions

\begin{tabular}{|c|c|c|c|c|}
\hline $\begin{array}{l}\text { Swelling in } \\
\text { Longitudinal } \\
\text { Direction }\end{array}$ & $\begin{array}{l}\text { Swelling in } \\
\text { Tangential } \\
\text { Direction }\end{array}$ & $\begin{array}{l}\text { Swelling in } \\
\text { Radial } \\
\text { Direction }\end{array}$ & $\begin{array}{c}\text { Water } \\
\text { Absorption }\end{array}$ & Treatments \\
\hline $\begin{array}{c}0.17 \\
\mathrm{NS}(+)\end{array}$ & $\begin{array}{c}0.84 \\
\text { NS (+) }\end{array}$ & $\begin{array}{l}0.88 \\
*(+)\end{array}$ & $\begin{array}{c}0.37 \\
\mathrm{NS}(+)\end{array}$ & $\begin{array}{c}\text { R square } \\
\text { (Gas Permeability) }\end{array}$ \\
\hline $\begin{array}{c}0.43 \\
\text { NS (-) }\end{array}$ & $\begin{array}{l}0.55 \\
\text { NS (-) }\end{array}$ & $\begin{array}{c}0.42 \\
\text { NS (-) }\end{array}$ & $\begin{array}{c}0.54 \\
\text { NS (-) }\end{array}$ & $\begin{array}{l}\text { R square } \\
\left(1^{\text {st }} \text { Drop }\right)\end{array}$ \\
\hline $\begin{array}{l}0.411 \\
\text { NS (-) }\end{array}$ & $\begin{array}{c}0.49 \\
\text { NS (-) }\end{array}$ & $\begin{array}{c}0.51 \\
\mathrm{NS}(-)\end{array}$ & $\begin{array}{c}0.28 \\
\mathrm{NS}(+)\end{array}$ & $\begin{array}{c}\text { R square } \\
\text { (50-mmLowering) }\end{array}$ \\
\hline $\begin{array}{l}\text { Statistically sig } \\
\text { Not Significar } \\
\text { positive }(+) \text { neg }\end{array}$ & $\begin{array}{l}\text { the } 5 \% \text { con } \\
\text { orrelation }\end{array}$ & level. & & \\
\hline
\end{tabular}

Cluster analysis of the $4+1$ treatments based on gas and liquid permeability values, as well as physical and mechanical properties (Talaei et al. 2011), also showed similarity between treatments in buffered hot water of $\mathrm{pH} 7$ and 8, as well as treatments in hygrothermal and hydrothermal (Fig. 4). 


\section{Rescaled Distance Cluster Combine}

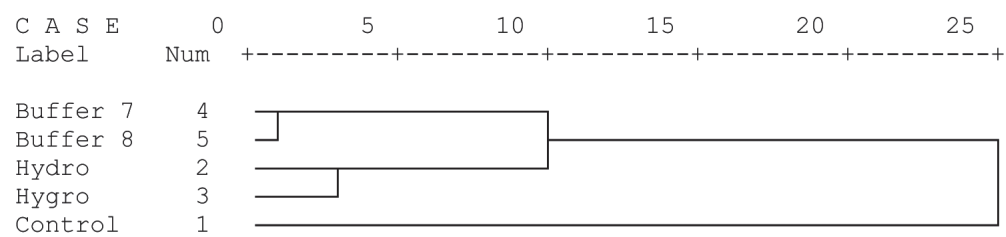

Figure 4. Cluster analysis of the 5 treatments based on gas and liquid permeability times ( $1^{\text {st }}$ drop and 50 -mm-lowering time) as well as physical and mechanical properties.

\section{CONCLUSION}

Based on the results and statistical analysis in the present study, it may be concluded that hydrothermal and hygrothermal treatments drastically decrease permeability in beech wood. This decrease in permeability may be mostly due to deposition of extractives on vessel perforations and cell walls blocking fluid transfer through the porous media. However, gas and liquid permeability can be increased in buffered hot water of $\mathrm{pH} 8$. Considering the low decrease in mechanical properties resulted from this treatment (buffered hot water of $\mathrm{pH}$ 8) (Talaei et al. 2011), this wood modification method is recommended for applications in which higher permeability is needed. With regard to high R-square between gas permeability and the amount of swelling in radial, as well as tangential, directions, it can also be concluded that gas permeability may be considered a suitable criterion for predicting the amount of swelling.

\section{ACKNOWLEDGMENT}

Authors feel indebted to Engin. Hossein Afshar, MD of Afshar Wood Group, being instrumental in the thermal treatments. We also pay tribute to the contribution of Mr. Mohsen Lotfalizadeh Mehrabadifor technical consultation and support. We appreciate efforts done by Mr. Hamed Bakhshi Ahangar and Mr. Meisam Safari (Wood Science and Technology Scientific Association of Shahid Rajaee Teacher Training University) for their great help in gas permeability specimen preparation and measurement.

\section{REFERENCES}

Alexeyev, V. 1967. Qualitative Analysis, Mir Publishers, Moscow, Russia. 470pp.

Boonstra, M.J.; Rijsdijk, J.F.; Sander, C.; Kegel, E.; Tjeerdsma, B.; Militz, H.; van Acker, J.; Stevens, M. 2006. Microstructural and Physical Aspects of Heat Treated Wood, Part 2, Hardwoods. Maderas. Ciencia y tecnologia 8(3): 209- 217.

Borrega, M.; Karenlampi, P.P. 2009. Hygroscopicity of Heat-Treated Norway spruce (Picea abies) wood. Eur. J. Wood Prod. DOI 10.1007/s00107-009-0371-8.

Burmester, A. 1981. Dimensional stabilization of wood. International Research Group on Wood Preservation, Doc. No. IRG/WP 3171. Sweden. $8 \mathrm{p}$

Elder, T. 1991. The Pyrolysis of Wood; In: Wood and Cellulosic Chemistry, Hon, D.N.S. and Shiraishi, N. (Eds.). Marcel Dekker, New York, USA: 66- 699.

Flynn, K. 1995. A Review of the Permeability, Fluid Flow, and Anatomy of Spruce (Picea spp.). Wood and Fiber Science 27(3): 278-284. 
Garrote, G.; Dominguez, H.; Parajo, J.C. 1999. Hydrothermal Processing of Lignocellulosic Materials. HolzalsRoh-und Werkstof 57 (3): 191- 202.

Gunduz, G.; Korkut, S.; Aydemir, D.; Bekar, I. 2009. The Density, Compression Strength and Surface Hardness of Heat Treated Hornbeam (Carpinus betulus L.) Wood. Maderas. Ciencia y tecnologia 11(1): 61-70.

Hill, C. 2006. Wood Modification Chemical, thermal and other processes; John Wiley \& Sons, Ltd., ISBN: 0-470-02172-1; 239pp.

Koch, P. 1996. Lodge pole Pine in North America. Madison, Wisconsin, Forest Products Society; USA. $343 p p$

Repellin, V.; Guyonnet, R. 2007. Evaluation of heat treated wood swelling by differential scanning calorimetry in Relation with Chemical Composition. Holzforschung 59(1) 28- 34.

Rice, R.W.; D’Onofrio, M. 1996. Longitudinal Gas Permeability measurements from Eastern White Pine, Red Spruce, and Balsam Fir. Wood and Fiber Science 28(3): 301-308.

Rousset, P.; Perré, P.; Girard, P. 2004. Modification of mass transfer properties in poplar wood (P.robusta) after a thermal treatment at high temperature. HolzRoh-Werkst 62(2): 113-119.

Siau, J.F. 1971. Flow in Wood. Syracuse University Press, Syracuse. 131pp.

Siau, J.F. 1995. Wood: Influence of Moisture on Physical Properties; Blacksburg, VA, Department of Wood Science and Forest Products Virginian Polytechnic Institute and State University, 1-63.

Stamm, A.J.; Burr, H.K.; Kline, A.A. 1946. Staybwood. Heat Stabilized Wood. Industrial and Engineering Chemistry 38 (6): 630 - 634.

Taghiyari, H.R.; Karimi, A.N.; Parsapajouh, D.; Pourtahmasi, K. 2010. Study on the Longitudinal Gas Permeability of Juvenile Wood and Mature Wood. Special Topics \& Reviews in Porous Media 1(1): 31-38. DOI: 10.1615/SpecialTopicsRevPorousMedia.v1.i1.30. Begell House, inc. publishers

Taghiyari, H.R.; Sarvari-Samadi, Y. 2010. Ultimate Length for Reporting Gas Permeability of Carpinus betulus Wood. Special Topics \& Reviews in Porous Media 1 (4): 345-351. DOI: 10.1615/SpecialTopicsRevPorousMedia. v1.i4.60. Begell House, inc. publishers

Taghiyari, H.R. 2011. Study on the Effect of Nano-Silver Impregnation on Mechanical Properties of HeatTreated Populus nigra. Springer-Verlag. Wood Sci. and Tech. 45: 399-404. DOI 10.1007/s00226-010-0343-5.

Taghiyari, H.R.; Efhami, D.; Karimi, A.N.; Pourtahmasi, K. 2011. Study on the Effect of Initial Spacing on Gas Permeability of Populus nigra betulifolia. Journal of Tropical Forest Science, Forest Research Institute Malaysia (FRIM) 23(3): 305- 310.

Taghiyari, H.R.; Efhami, D. 2011. Diameter increment response of Populus nigra var. betulifolia induced by alfalfa. Austrian Journal of Forest Science 128 (2): 113- 127.

Taghiyari, H.R. 2012. Correlation between Gas and Liquid Permeabilities in some Nano-Silver-Impregnated and Untreated Hardwoods. Journal of Tropical Forest Science, Forest Research Institute Malaysia (FRIM) 24(2): (in press).

Talaei, A.; Karimi, A.N.; Ebrahimi, G.H.; Mir-Shokraei, S.A. 2011. Comparative Study of Heat-Treated Beech Wood in Hot Water and Steam Mediums. Iranian Wood and Paper Scientific Association Journal (in press).

Tiemann, H.D. 1915. The Effect of Different Methods of Drying on the strength of Wood. Lumber World Review 28 (7): 19-20. 